\title{
Golden jackal, a natural disperser or an invasive alien species in Slovakia? A summary within European context
}

\author{
Peter Urban $^{1 *}$, Nuno Guimarães ${ }^{2,3}$, Jozef Bučko $^{4}$
}

${ }^{1}$ Faculty of Natural Sciences, Matej Bel University, Tajovského 40, 97401 Banská Bystrica, Slovakia

${ }^{2}$ Faculty of Humanities and Natural Sciences, University of Prešov,

17. novembra 1, 08116 Prešov, Slovakia

${ }^{3}$ Diana - Carpathian Wildlife Research, Mládežnícka 47, 97404 Banská Bystrica, Slovakia

${ }^{4}$ Institute for Forest Resources and Information, National Forest Centre,

Sokolská 1/2, 96001 Zvolen, Slovakia

\begin{abstract}
Urban, P., Guimarães, N., BučKo, J., 2020. Golden jackal, a natural disperser or an invasive alien species in Slovakia? A summary within European context. Folia Oecologica, 47 (2): 89-99.

This summary provides an overview of the golden jackal (Canis aureus) categorization in Europe with particular focus on its presence in Slovakia. The distribution range of this species in Europe has been expanding in recent decades. Currently, European population is in constant and fast increase, widening their ranges towards Central and Eastern Europe and more recently in some western countries. All over Europe, the categorization of the golden jackal status is discussed with some controversial. A recent genetic study helped to determine that golden jackals do not meet the established three criteria, which categorize a species as an invasive alien species. In Slovakia, golden jackals' numbers grown considerably in the last decade and with an increasing of their distribution through the country it became a permanent species of the Slovak fauna. The only internal status is the hunting Act no. 274/2009, which classifies it as, game species. The fast adaptation and dispersion through Slovakia can be considered similar to the behaviour of an invasive species, as suggested in previous studies in Hungary. Based on widely accepted definitions, agreed under international legal instruments, it is quite clear that the term 'Invasive Alien Species' only encompasses non-native species specifically introduced by humans (intentionally or accidentally). Following this Invasive Alien Species terminology, golden jackals cannot be categorized as such in Slovakia. The natural expansion, the growing ranges, and the increase in numbers of the golden jackal in Slovakia in the last decades points to a need to improve the knowledge of the species.
\end{abstract}

\section{Keywords}

adaptation, alien species, dispersion, distribution, effects, invasion

*Corresponding author:

e-mail:urban.lutra@gmail.com 


\section{Introduction}

The golden jackal (Canis aureus moreoticus Geoffrey 1835) is a middle-sized carnivore (mesocarnivore, $5-15 \mathrm{~kg}$ ) from the genus Canis (Linnaeus, 1758). It is one of the most widespread canid species in the world (SILLERO-ZUBIRI et al., 2004). Its high adaptability to a large variety of habitats, opportunistic predator behaviour and omnivorous diet makes it a true generalist species. The golden jackal is a much social species, living in pairs or groups composed generally by the breeding pair and their offspring, at least until adult size, thus forming temporary large groups (MACDONALD, 1978). Dispersing individuals are mostly solitary vagrants in search of suitable territory and/or a partner (NEGI, 2014). The actual range of this species covers many countries in Europe and Asia (SILLERoZubiri et al., 2004; ArNOLD et al., 2012; KoEPFli et al., 2015; RutKowski et al., 2017; HoffMAn et al., 2018). Since the most recent dispersion wave from the Balkans in the 1980s, they are still expanding their range through Europe as shown by an increasing number of individuals recorded far outside of their known historic geographical range (KROFEL, 2009; ARNOLD et al., 2012; RUTKOWSKI et al., 2015; Trouwborst et al., 2015; Krofel et al., 2017; BogDANOwicz et al., 2018). During the last fifty years, records in Europe show a clear increasing trend, with significant fluctuations, in the size and distribution of the golden jackal population. There are presently records of golden jackal reproduction from most of South-Eastern Europe, parts of eastern and central Europe and more recently recorded in some western countries (TROUwBORsT et al., 2015; JiRKů et al., 2018; KowALCZYK et al., 2020). In past decade, golden jackal numbers grew in Slovakia and together with the increase of its dispersion range through the country become a permanent species of the Slovak fauna, although there are no clear evidence of its reproduction (Urban et al., 2017; GUIMARÃES et al., 2018, 2019).

The expansion of the golden jackal across Europe generated many concerns about its negative effects on wildlife (essentially endangered and game species) and livestock (e.g. via predation or transmission of pathogens of zoonotic and veterinary importance) which lead to its categorization as an invasive alien species (IAS) in the Baltic States (RutKowski et al., 2015; StratFord, 2015; ANONYMOUS, 2016). However, it is important to refer that as all mesocarnivores, they also present many positive effects in the ecosystem being the animal waste removal and control of crop pests the more relevant (ĆIROVIĆ et al., 2016). Currently, general question from many stakeholders (including researchers and local dwellers) is: will golden jackals influence native biodiversity, especially in areas where future reproductive pairs and new population clusters may occur? (HATLAUF and HACKLÄNDER, 2016).

Our aims with this golden jackal review is to summarize: (1) an overview of their dispersion/distribution and current status in Europe; (2) their historic dispersion and current status of jackals into and in Slovakia; (3) and clarify the categorization of the golden jackal in Slovakia (natural disperser or an IAS) according to national and international literary and legislative definitions.

\section{Golden jackal in Europe}

The historical range of the golden jackal in Europe was limited to coastal regions along the Adriatic coast in Croatia and the Mediterranean and Black sea regions of Greece and Bulgaria (MAlEz, 1984; SPASSOv, 1989; SOMMER and Benecke, 2005; Markov, 2012; Stoyanov, 2012; TrouWBORST et al., 2015; Krofel et al., 2017; SPASSOV and Acosta-PANKov, 2019). The only paleontological records available are from the Middle Holocene what indicates that this species was absent from Europe in the Pleistocene (SOMmer and BenECKe, 2005; SPASSOV and ACOSTA-PANKOV, 2019). The absence of fossil and subfossil remains from the species, inclusive in their main core area (SouthEastern Europe), suggest a probable late dispersal, potentially influenced by anthropogenic activities (SPASSOV and Acosta-Pankov, 2019).

In the second half of the 19th century, golden jackals dispersed from the South-Eastern Balkans along the Danube Basin as far as Hungary (Tóth et al., 2009; HofFMANN et al., 2018). During the first half of 20th century, the distribution of the species was restricted to South-Eastern Europe with some particular occurrences in Hungary (SZUNYOGHY, 1957, 1959; NAGY, 1959; MoŠANSKÝ, 1983; Tóth et al., 2009; Spassov and ACOSTA-PANKov, 2019). The European population of the golden jackal declined and there were local extinctions in the Pannonian region in the mid-20th century, due to anthropogenic factors like habitat fragmentation, culling practices, intensive hunting and poisoning (Demeter, 1984; KoubeK and ČErVEnÝ, 2007; Tо́тн et al., 2009). In this time, small and scattered resident groups of golden jackal persisted along the coasts of the Balkan Peninsula (AtANasov, 1953). Following conservation measures, targeting golden jackals, in some key regions in the Balkan around 70's (e.g. Greece, Bulgaria), they started to expand and increase their range from these areas to North and Northwest (Demeter and Spassov, 1993; Giannatos et al., 2005; Stoyanov, 2012). Particularly in Bulgaria the distribution of golden jackals increased up to 33-fold between 1962 and 1985 (KRYŠTUFEK et al., 1997). Because of this, within the 70's, and due to the damages on livestock attributed to them, their numbers had to be regulated (STOYANOv, 2012).

During the 80 's, due to the almost extirpation of some core populations, the conservation actions increased including the reduction of hunting (e.g. Strandja between Bulgaria and Turkey, Dalmatian Coast, Aegean in Macedonia). With these actions, the golden jackal recovered and not just recolonized its previous range but also dispersed into new areas (ARNOLD et al., 2012; BANEA et al., 2012; Trouwborst et al., 2015). The dispersion of the golden jackal was recorded mainly along the eastern Adriatic coast (KRYŠTUFEK and TVRTKOVIC, 1990; JHALA and Moehlman, 2008; Krofel and PotoČNiK, 2008) and the mainland lowlands of South-Eastern and Central Europe (TótH et al., 2009).

Within the last two decades, it has spread throughout Central Europe and with the continuous expansion of the distribution range of the golden jackal, it started to integrate the list of local fauna in many countries. 
(e.g. KRYŠTUfEK et al., 1997; Heltai et al., 2000; SzABó et al., 2009; ARNOLD et al., 2012; RUTKOWSKI et al., 2015; Trouwborst et al., 2015; Hatlauf and HackläNDER, 2016; PYŠKoví et al., 2016; KrofEL et al., 2017; JiRKU゚ et al., 2018). Some areas, which occasional occurrences of vagrant animals were firstly reported, became areas of permanent residence of territorial groups the following years and/or decades (KROFEL, 2009). Dispersed animals have been observed further to the North and West of Europe (e.g. Germany, Poland, Denmark, the Baltic States, Finland, the Netherlands, France) (e.g. Möckel, 2000; WEINGARTH et al., 2012; BANEA et al., 2013; KowALCZYK et al., 2015, 2020; MARAN, 2015; RutKowsKi et al., 2015; StratFord, 2015; PyšKová et al., 2016; PaulausKas et al., 2018). This expansion made the golden jackal one of the most abundant carnivore species with a population size estimated to be between 97,000 and 117,000 individuals in Europe (RANC et al., 2019). Its reproduction has been reported rarely in the area of expansion (JIRKU et al., 2018; KOWALCZYK et al., 2020).

Long-distance dispersion (DEMETER and SPASSOV, 1993; RutKowski et al., 2015) was possible due to migration along water bodies (SzABó et al., 2006). The absence of larger predators seems to favour the recovery of the species in many areas (KRYŠTUFEK and TVRTKOVIČ, 1990; Giannatos, 2004), especially the grey wolf (Canis lupus). Areas where wolves are present, but at the same time persecuted and culled, brings instability to the resident packs. This instability in wolf packs is considered a major factor for the expansion of jackals throughout many regions in Europe (KROFEL et al., 2017; NewsOME et al., 2017). Other suggested factors behind the survival and expansion of the species are the plasticity and land-use changes (Š́́LEK et al., 2014). Land use changes include deforestation, development of a road and railway network, additional availability of food sources related to human activities (SPASSOv and Acosta-Pankov, 2019), changes in hunting practices (MARKOV and LANSZKI, 2012) and warming of the climate, creating favourable conditions for golden jackal in Central Europe (Giannatos, 2004; ARNOLD et al., 2012). Their habitat preferences in Europe have generally been described as cultivated areas and wetlands located in lower elevations and heterogeneous habitats with adequate cover for hiding and breeding ( ̌́ ÁLEK et al., 2014; HoffMAN et al., 2018).

Legally, in Europe the golden jackal is under many international regulations such as the Bern Convention in 1979 (ANONYMOUS, 1979; Ausems, 1980; https://www. coe.int/en/web/bern-convention), the Convention on Biological Diversity (CBD) in 1992 (AnONYMous, 1992a; https://www.cbd.int/doc/legal/cbd-en.pdf), and the European Union (EU) Habitats Directive 92/43 EC in 1992 too (AnONymous, 1992b). Within the EU directive, golden jackal is listed in Annex V, categorizing it as a species of Community interest, with the management done in accordance with ecological characteristics and needs of the species and ensuring that culling will imply a maintenance of a favourable sustainable conservation status. In 14 out of 26 countries west of the Black Sea, where the species' presence has been confirmed, golden jackals may be hunted in accordance with national hunting legislation, which in many cases includes a defined hunting season (e.g. Montenegro, Romania, Slovakia, Slovenia) (TrouwBORST et al., 2015).

\section{Golden jackal in Slovakia}

The increase of the species abundance in Hungary and its distribution in the 1980s, it is an indicator of how and from where the golden jackals arrive in Slovakia (DEMETER and Spassov, 1993; Hell and RajSKÝ, 2000; Heltai et al., 2000; SzABó et al., 2009). The first official golden jackal record in Slovakia originated in 1989, when one individual was shoot near Čierna village in the southeast part of the country ( $6 \mathrm{~km}$ from the Hungarian and Ukrainian borders) (MošAnSKÝ, 1995; ARNOLD et al., 2012; DANKo, 2012; GuimarÃes et al., 2018, 2019). Nevertheless, it is still not clear if golden jackals were present in the past and so it is possible that they are making a return to old habitats (Bethlenfalvy, 1952; Szunyoghy, 1957, 1959; Nagy, 1959; JANOviČOvÁ, 2016). The data include four golden jackal historical records from Hungary, with one from the 19th century, not far from the border with Slovakia: first record is from 1882, when one individual was shoot near the village of Debrö (43 km from the border); second record occurred in 1892 and refers to one animal observed in Tarcal village ( $46 \mathrm{~km}$ from the border) near the river Tisa; third record, refers to a shot individual in 1937, near Tyukod village $(69 \mathrm{~km}$ from the border); fourth record, near Derecske $(110 \mathrm{~km})$, relates to one more shot individual in 1942 (MoŠAnskÝ, 1983). These records so near to Slovakia, can in fact be very important to confirm the originality of an uncertain record from 1945, when four golden jackal pelts (one adult and three juveniles), where found in a fur collection in Bratislava (FERIANC, 1955; FERIANCOvíMasáRové and HANÁK, 1965) allegedly shot in Žitný ostrov Island (14 km from the border to Hungary). Following the first official record from 1989, three records of animals shot between 1995 and 1997, in the southern part of the country (Hell and BlehO, 1995; Hell and RaJSKÝ, 2000; RAJSKÝ and NAGY, 1998; RAJSKÝ et al., 2005; Guimaraes et al., 2019). Afterward groups, vagrants, and young dispersal individuals were sporadically recorded in Slovakia, with more incidence in the East Slovakian lowland (probably along watercourses - Bodrog, Latorica, Ondava etc.), the south of central Slovakia (Ipel' river basin and surrounding mountains), and the Danube region (GuIMARAES et al., 2019). Within the new millennium, the number of records of the presence of the golden jackal (observed, shot, and data collected by the means of acoustic monitoring) increased gradually. Nowadays is dispersed through all the country (Fig. 1), being the south and East regions the areas with the highest population density of jackals (SLAmKa et al., 2017; URBAN and RAJSKÝ, 2018; GuimarAEs et al., 2019). Habitats in the overall range is very diverse, from forests to bushlands, from river basins to mountains being nowadays present in both Alpine and Pannonian biogeographical regions. There are more cases of jackal mortality on the roads throughout the country. 


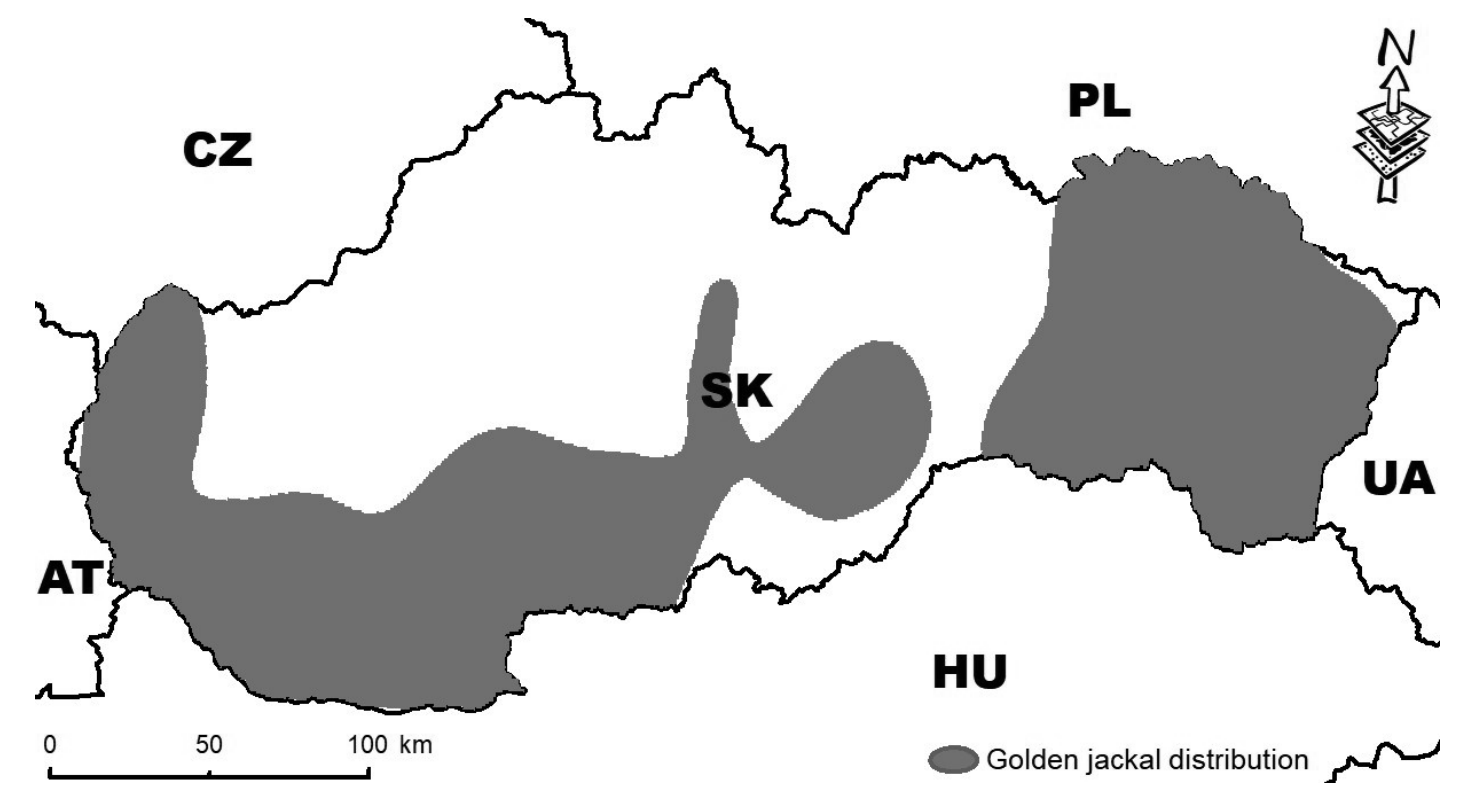

Fig. 1. Approximate distribution of the golden jackal population in Slovakia. Dark shaded areas: areas with consistent presence data, from the shot and observed individuals along the years 2008-2018 (GuIMARÃES et al.).

This expansion and dispersion through Slovakia generated increased interest in this species, resulting in many publications on this issue in recent years (URBAN and RAJSKÝ, 2018). The conservation status of the golden jackal in Slovakia, over the last 15 years has changed several times. Between 2001 and 2009 year-round protection was given to the golden jackal mainly because of the absence of data. In 2009, it became a hunting game species with the established hunting season from September to the end of January. In 2014, the hunting season was readjusted and it is up to date from August until the end of February (ANONYMOUs, 2009a).

According to Slovak hunting statistics, the official numbers and estimation of the golden jackal increased annually, from three individuals shot and 8 individuals reported in 2009, up to 44 shot and 444 reported individuals in 2019, representing approximately 15 times more the number of first culled data and 55 time more the individuals estimates (Fig. 2 and 3) (ANONYMOUs, 2020).

In the latest update of the Red List of Mammals of Slovakia, golden jackals' were classified as a species with Data Deficient (UrBAN et al., 2019, 2020). In the previous Red List this species was not rated but it was categorized as a permanent species in Slovakia (Žiak and URBAN, 2001).

Despite the increase in information on its distribution, hunting, and mortality on roads, corresponding to its dissemination in the Central European area, there is no further information for a serious classification of this species into one of the IUCN threatened species categories (URBAN et al., 2020).

\section{Golden jackal a natural disperser or an invasive alien species?}

All over Europe, controversial discussion about the categorization of the golden jackal status increased in the last years. As an example, in 2015 golden jackals were defined an alien and potentially invasive alien species in the Baltic States (RUTKOWSKI et al., 2015; STRATFORD, 2015). In order to be categorized as an invasive alien species it would need to match with the three-point criteria established by the CBD in 2009: (1) be non-native or allochthonous species and specifically introduced by man; (2) threaten biological diversity on the local scale; (3) be characterized by rapid population growth. In fact, these criteria for categorization as an 'alien species', only include species that have been introduced by man (intentionally or accidentally). This factor automatically excludes golden jackals migration dispersal is proven to be natural, and it was not introduced in any part of its actual dispersion range, even though it is beyond their historic core range.

Under the Regulation (EU) No. 1143/2014 of the European Parliament and of the Council of 22nd of October 2014 on the prevention and management of the introduction and spread of invasive alien species, quite clear includes in its consolidated text (ANONYMOUS 2014, 2019a):

- 'invasive alien species' corresponds to a species whose introduction or spread has been found to threaten or adversely impact upon biodiversity and related ecosystem services,

- 'invasive alien species of Union concern' means an invasive alien species whose adverse impact has been deemed such as to require concerted action at Union level pursuant to Article 4(3),

- 'invasive alien species of Member State concern' means an invasive alien species other than an invasive alien species of Union concern, for which a Member State considers, on the basis of scientific evidence, that the adverse impact of its release and spread, even where not fully ascertained, is of significance for its territory, or part of it, and requires action at the level of that Member State. The golden jackal is not included in the List of Invasive Alien Species of Union concern 


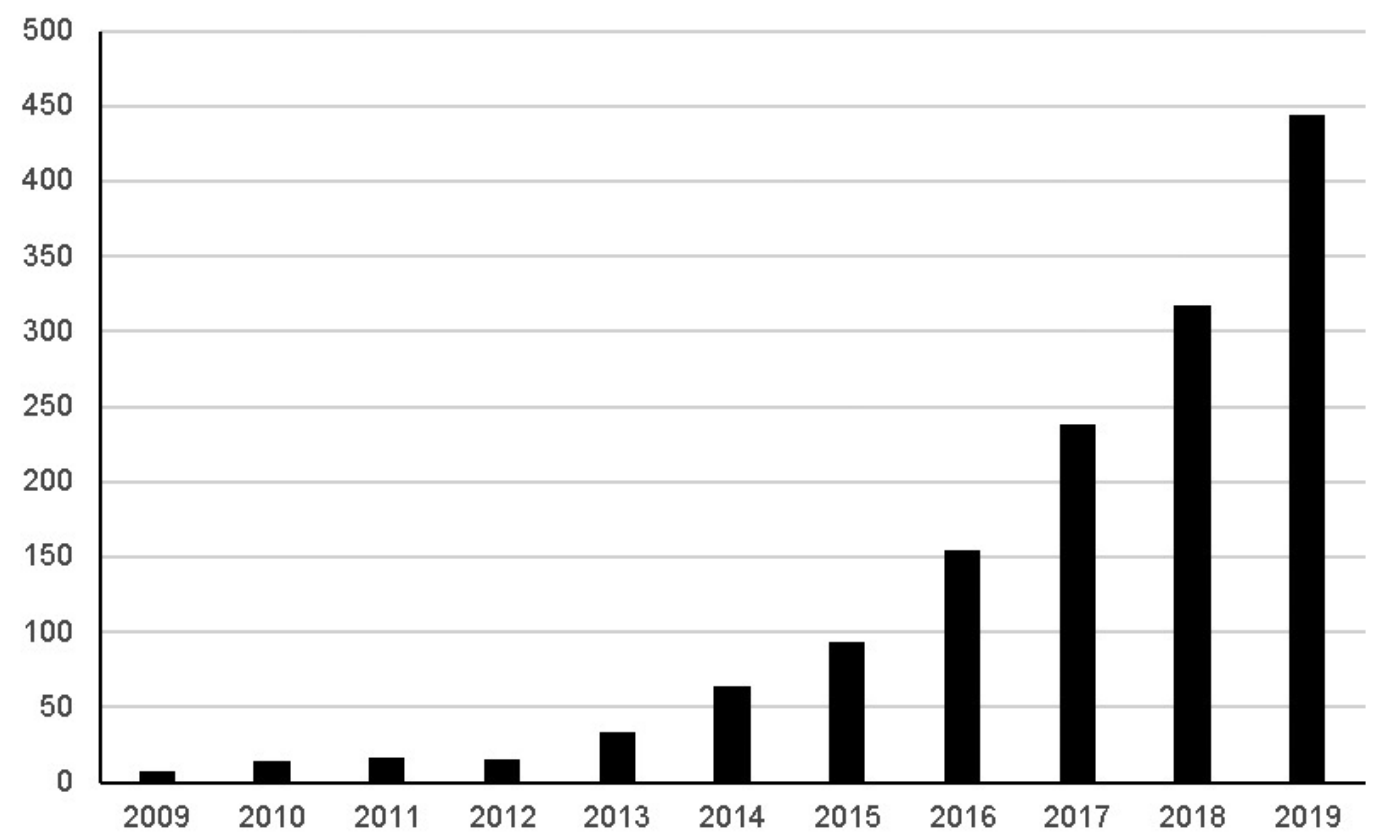

Fig. 2. Overview of the reported numbers (expert estimates) of the golden jackals in Slovakia along the years 2009-2019. Sources: the Hunting Database in the National Forest Centre, Institute for Forest Resources and Information in Zvolen; hunting statistical yearbooks.

drawn up on the basis of this regulation, which entered into force on the 4th of August of 2016 (ANONYMOUS, 2017). Nevertheless, a factor from the actual expansion that can be overlooked and considered as similar to the behaviour of an IAS, is the rapid growth in population numbers, high prolific rates, great dispersion capacity, phenotypic plasticity and ability to survive on various food types and in a wide range of environmental conditions, which is a characteristic of an IAS (ANONYMOUS, 2009b), also suggested in previous studies in Hungary (SzABó et al., 2007; Heltai et al., 2018)

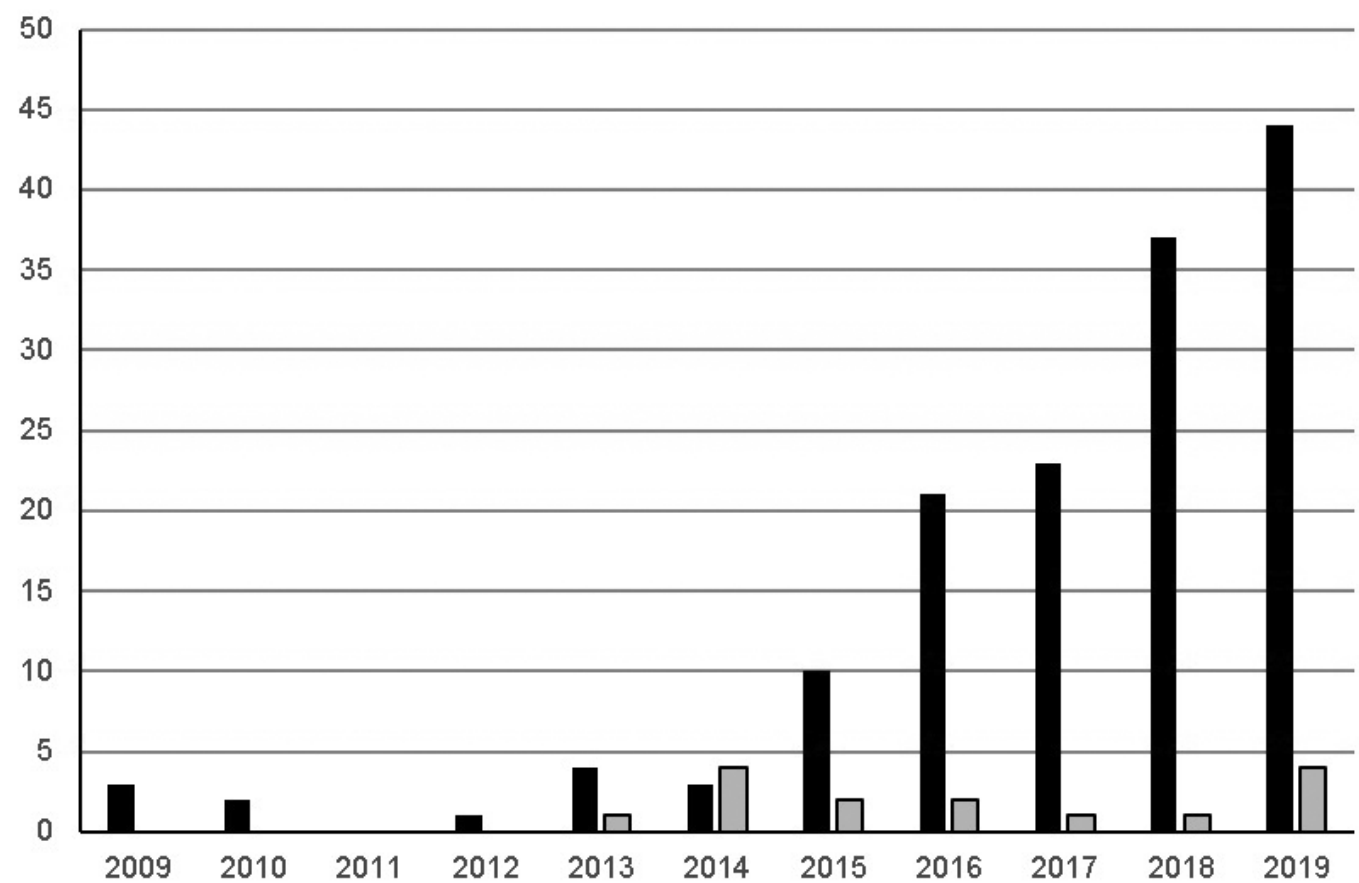

Fig. 3. Overview of the numbers of shotted and found dead individuals of the golden jackal in Slovakia along the years 20092019; black colour: shotted, grey colour: found dead. Sources: the Hunting Database in the National Forest Centre, Institute for Forest Resources and Information in Zvolen; hunting statistical yearbooks; KIMS - Complex Information and Monitoring System (www.biomonitoring.sk). 
A study realized by RUTKOWSKI and collective (2015), brought important scientific evidence allowing to determine golden jackals categorization. The results from this study suggested that the golden jackal's colonization in the Baltics has origins within two different 'waves' of dispersion from two different populations. The first 'wave', determined on analysed samples from Estonia, indicates with high probability that these animals originated from the Caucasus region via Ukraine. The second 'wave', with analysed samples from Lithuania, relates its origins with animals from south-eastern Europe, through an expansion front within Romania, Hungary/western Ukraine, Slovakia and Poland (RutKowski et al., 2015; AnONymous, 2016). Both waves clearly represent a continuous natural expansion of the species (RUTKOWSKI et al., 2015). Thus, the fact that historic occurrence of the species cannot be proven within a recently colonized territory, does not imply that simple spread outside their natural range as the ecologic characteristics of the species such as the high adaptability to new habitats, need to be added in account when categorizing the species (TrouwBorst et al., 2015).

\section{Conclusions}

Does the golden jackal in Slovakia meet the conditions of the stated criteria of an invasive alien species? The facts are:

1. Official records of the occurrence of golden jackals in Slovakia is absent prior to 1989 , with the exception of the specimens from the 19th century. Golden jackals have no registers as a trophy from former feudal lords in the expositions of museums or castles and palaces.

2. The rapid population growth of the golden jackal's, it is based on the data from official hunting statistics (see Fig. 2 and 3).

3. The jackal was not introduced by humans into Slovakia, migrating naturally and spontaneously.

Recent records of jackal occurrence from Slovakia, Ukraine, Belarus, and north-western and eastern Poland, suggest that both Caucasian and south-eastern European populations are both spreading towards the north (RUTKOWSKI et al., 2015).

With the rapid increase of the golden jackal population size along its range, there is still limited evidence that its presence has an influence on endemic fauna and that it is a possible threat to local biological diversity.

Nevertheless, the definitions of invasive species referred above exclude any hypothetical categorization of the golden jackal as an IAS, as the based criteria relate to IAS as species outside their regular range introduced by humans, what in fact did not occur in Slovakia (LiNNELL et al., 2015; RutKowsKi et al., 2015; TrouwBorst et al., 2015; AnONymous, 2016). The golden jackal is not included in the List of non-native invasive species of concern to the Slovakia (AnONYmous, 2019b).

As widely accepted definitions agreed under international legal instruments make it quite clear that the term 'alien species' only encompasses creatures originating from introductions outside their regular range made by man. It is possible to conclude that golden jackal was not introduced by humans into Slovakia, but disperse naturally and spontaneously and should thus not be regarded as IAS.

Although, given the current state of biodiversity in the lowland-agricultural land, the spread of jackals in Slovakia is a cause for concern for many stakeholders, especially the competition with hunters on game species (e.g. roe deer, hares, pheasants and quail). The presence of some endangered species of birds and other small endemic mammals can generate impacts (ecologic and economics) and need to be taken into consideration that control of the species might be necessary always based on scientificbased data.

Competition with red foxes (Vulpes vulpes) it is much probable expected, as reported in previous studies. They both inhabit similar habitats and overlap food habits (e.g. rodents, carrion), what can represent direct impacts on rodents, brown hare and roe deer as presented with other predatory species all over the world (LANSZKI and HELTAI, 2002; LANSZKI et al., 2006, 2016; RADOvić and KovaČIĆ, 2010; KIDAWA and KowalCZYK, 2011; Markov and LANSZKI, 2012; ĆIrović et al., 2014; PenEZIĆ and ĆIrović, 2015; KowAlCZYK et al., 2015; HaYWARD et al., 2017; SAISAMORN et al., 2019). Although there is no published data is also much probable to occur direct competition with the invasive raccoon dogs (Nyctereutes procyonoides), due to the same reasons determined with golden jackals and red foxes. Eurasian golden jackal significantly prefers to prey on brown hare (Lepus europaeus; $4 \mathrm{~kg}$ ), yielding a predator to preferred prey mass ratio of 1:0.6, and a preferred and accessible prey weight range of $0-4 \mathrm{~kg}$ and $0-15 \mathrm{~kg}$, respectively. Significantly avoided ungulates in general and red deer specifically, pheasant and small mammals (HAYWARD et al., 2017).

Viscera and carrion of wild ungulates were found, in an area of intensive big game management in Hungary, to be the primary food of jackals in every season (wet weight: $55 \%$ ), and in addition, consumption of adult wild boar and cervids proved remarkable (LANSZKI et al., 2015).

There is a chance that golden jackals may have a negative impact in endangered species (BROWN and MACDONALD, 1995), but this needs further research in order to determine whether this was the case. The diet preferences of golden jackals are driven up by both top-down and bottom-up factors because of the presence of apex predators as well as prey size and birthing behaviour affected their prey (HAYWARD et al., 2017). On the other hand, it is important to emphasize the fact that the presence of golden jackals can have substantial positive impacts as ecosystem cleaners as suggested by ĆIROvić and collective (2016). Their study pinpoint that ecological services of golden jackals are more positive than negative for two reasons: the importance of the removal of animal carcasses discarded by humans and as an important tool in the crop pest control. It is then also much probable that golden jackals can have positive effects within contaminated carcasses of wild boars from African swine fever by reducing the prevalence of contaminated carcasses within their habitat, but further analysis are needed concerning their diet habits. 
As described in other regions, the presence of the three large carnivores in Slovakia (Ursus arctos, Canis lupus, and $\operatorname{Lyn} x \operatorname{lynx}$ ) can be a limiting factor for the expansion and establishment of the species through the entire country (Krofel et al., 2017; Newsome et al., 2017). Therefore, the interaction and sympatry between species in further field surveys and other studies should be assessed (GUIMARÃES et al., 2019).

The golden jackal is currently a species that is part of the local fauna and it is still expanding its range through Slovakia. Nevertheless, the natural expansion, the growing ranges and the increase on numbers of the golden jackal in Slovakia in the last decades requires the need to improve the knowledge on the species, systematic scientific based monitoring and the preparation a management plan for this species (URBAN et al., 2017). Due to widely accepted definitions, it becomes clear that golden jackal are natural dispersers, based on the scientific arguments presented along this summary, and they should not be categorized as an IAS.

We can conclude that golden jackals should be categorized as a new fauna species and it will need laws according to these criteria and according to the ecology of the species. At the same time the hunting of this species should be also adapted to their ecology, at least until more scientific data is gathered, which will bring a more real situation and therefore allow a more accurate management and not dealing with probabilities and possibilities. Even though some studies are already available from other parts of its range the situation can be much different in Slovakia at least in areas where golden jackals will meet with large carnivores which will for sure control their numbers.

\section{Acknowledgements}

The project Kega No. 036UMB-4/2018 supported this study. We would like to thank Miklós Heltai, Peter Kušík and Dušan Rajský for their precious advice and information. We are also grateful to L'udmila Sabová, Peter Sabo, and Gregg Losinski for proofreading.

\section{References}

AnONYmous, 1979. Convention on the Conservation of European Wildlife and Natural Habitats. 19. 9. 1979. [online]. Council of Europe. European Treaty Series, 104: 1-10. [cit. 02-09-2020]. https://rm.coe.int/CoERMPublicCommonSearchServices/DisplayDCTMContent?documentId $=0900001680078 \mathrm{aff}$

AnONYMous, 1992a. Council Directive 92/43 / EEC of 21 May 1992 on the conservation of natural habitats and of wild fauna and flora. [online]. Official Journal of the European Communities, L 206: 7. [cit. 02-09-2020]. http://data. europa.eu/eli/dir/1992/43/oj (including current consolidated version).

Anonymous, 1992b. Convention on Biological Diversity. [online]. United Nations. 28 p. [cit. 02-09-2020]. https:// www.cbd.int/doc/legal/cbd-en.pdf
ANONYMOUS, 2009a. Zákon č. 274/2009 Z. z. o pol'ovníctve a o zmene a doplnení niektorých zákonov [Act no. 274/2009 Coll. on hunting and on amendments to certain laws as amended]. Zbierka zákonov SR, 274 (96): $1854-1890$.

Anonymous, 2009b. The CBD and Invasive Alien Species. [online]. [cit. 05-07-2020]. https://www.cbd.int/ $\mathrm{idb} / 2009 /$ about $/ \mathrm{cbd} /$

AnONymous, 2014. Regulation (EU) No 1143/2014 of the European Parliament and of the Council of 22 October 2014 on the prevention and management of the introduction and spread of invasive alien species. [online]. Official Journal of the European Union, L 317: 35-55. [cit. 05-07-2020]. https://eur-lex.europa.eu/legal-content/EN/ TXT/?qid=1417443504720\&uri=CELEX:32014R1143

ANONYMOUS, 2016. Golden jackal should not be treated as an alien species in Europe. [online]. Science for Environment Policy, 443: 1-2. [cit. 05-07-2020]. https://ec.europa.eu/environment/integration/research/newsalert/pdf/ golden_jackal_should_not_be_treated_as_an_alien_species_in_europe_443nal_en.pdf

AnONymous, 2017. Invasive Alien Species of Union concern. [online]. Luxembourg: Publications Office of the European Union. [cit. 05-07-2020]. https://ec.europa.eu/ environment/nature/pdf/IAS_brochure_species.pdf

ANONYmous, 2019a. Commission Implementing Regulation (EU) 2019/1262 of 25 July 2019 amending Implementing Regulation (EU) 2016/1141 to update the list of invasive alien species of Union concern. [online]. Official Journal of the European Union, L 199: 1-4. [cit. 05-072020]. http://data.europa.eu/eli/reg_imp1/2019/1262/oj

ANONYMOUs, 2019b. Nariadenie vlády Slovenskej republiky 449 , ktorým sa vydáva zoznam inváznych nepôvodných druhov vzbudzujúcich obavy Slovenskej republiky [Regulation of the Government of the Slovak Republic no. 449/2019 Coll. issuing the list of invasive non-originals species of concern to the Slovak Republic]. Zbierka zákonov Slovenskej republiky, 449: 1-4. [cit. 05-07-020]. http://www.sopsr.sk/news/file/legislativa/449_2019_nariadenie_zoznam_invaznych_druhov.pdf

Anonymous, 2020. Polovnícka štatistická ročenka Slovenskej republiky 2019 [Hunting statistical yearbook of the Slovak Republic 2019]. Zvolen: Národné lesnícke centrum. 244 p.

Arnold, J., Hummer A., Heltai, M., Murariu, D., Spassov, N., HACKLÄNDER K., 2012. Current status and distribution of golden jackals Canis aureus in Europe. Mammal Review, 42 (1): 1-11. https://doi.org/10.1111/j.13652907.2011.00185.x

AtAnasov N., 1953. Study on the jackal (Canis aureus L.) in Bulgaria. Messages of Institute of Zoology and Museum BAN, 2: 189-273.

Ausems, E.J., 1980. Convention on the conservation of European wildlife and natural habitats. Environmental Conservation, 7 (2): 143-144.

Banea, O.C., Krofel, M., Červinka, J., Gargarea, P., SzaBÓ, L., 2012. New records, first estimates of densities and questions of applied ecology for jackals in Danube Delta Biosphere Reserve and hunting terrains from Romania. Acta Zoologica Bulgarica, 64: 353-366. 
BAneA, O., 2013. Jackals in West Estonia. 21 March 2013. [online]. In GOJAGE blog [Internet]. [about 18 screens]. [cit. 05-07-2020]. http://goldenjackalaround.blogspot. com/2013/03/golden-jackal-survey-in-w-estonia.html.

Bethlenfalvy, E., 1952. A természet kincsestárából [Treasures of nature]. 93 p. Msc.

Bogdanowicz, W., Heltai, M., Szabó, L., Lanszki, J., GIannatos, G., Banea, O.C., Kowalczyk, R., Krone, O., Volokh, A.M., Hulva, P., Gherman, C.M., Mihalica, A. D., Ionica, A.M., D'Amico, G., Modrú, D., JurÁnKová, J., Forejtek, P., ProkopchuK, V., Ćirović, D., Krofel, M., Bujalska, B., Patrzyk, M., Rutkowski, R., 2018. Complex genetic structure of the expanding golden jackal populations in Europe. In Giannatos, G., Banea, O.C., Hatlauf, J., Sillero-Zubiri, C., Georgiadis, C., LegaKIS, A. (eds). Proceedings of the 2nd international jackal symposium, Marathon Bay, Attiki, Greece 2018. Hellenic Zoological Archives, 9: 82-83.

Brown, L., Macdonald, D.W., 1995. Predation on green turtle Chelonia mydas nests by wild canids at Akyatan beach, Turkey. Biological Conservation, 71: 55-60.

Ćirović, D., Penezić, A., Krofel, M., 2016. Jackals as cleaners: Ecosystem services provided by a mesocarnivore in human-dominated landscapes. Biological Conservation, 199: 51-55.

Ćirović, D., Penezić, A., Milenković, M., Paunović, M., 2014. Winter diet composition of the golden jackal (Canis aureus L., 1758) in Serbia. Mammalian Biology, 79 (2): 132-137.

DANKo, Š., 2012. Šakal zlatý - Canis aureus [Golden jackal Canis aureus]. In KRIŠTofík, J., DANKo, Š., (eds). Cicavce Slovenska. Rozšírenie, bionómia a ochrana. Bratislava: Veda, p. 423-425.

Demeter, A., 1984. Recent records of rare or non-resident large carnivores in Hungary. Vertebrata Hungarica, 22: 69-71.

Demeter, A., Spassov, N., 1993. Canis aureus L. 1758 Schakal, Goldschakal [Canis aureus L. 1758-Jackal, Golden jackal] In StubBE, M., KRAPP, F. (eds). Handbuch Der Säugetiere Europas. Wiesbaden, Germany: AulaVerlag, p. 107-138.

Fabbri, E., Caniglia, R., Galov, A., Arbanasić, H., Lapini. L., BošKović, I., Florijančić, T., Vlasseva, A., Ahmed. A., MirChEv. R., Randi, E., 2014. Genetic structure and expansion of golden jackals (Canis aureus) in the northwestern distribution range (Croatia and eastern Italian Alps). Conservation Genetics, 15: 187-199. doi: 10.1007/ s10592-013-0530-7.

Ferianc, O., 1955. Príspevok k stavovcom Žitného ostrova I [Contribution to vertebrates in Žitný ostrov Island I]. Biologia, Bratislava, 10: 308-324.

Feriancová-Masárová, Z., HanÁK, V., 1965. Stavovce Slovenska 4. Cicavce [Vertebrates of Slovakia 4. Mammals]. Bratislava: Vydavatel'stvo Slovenskej akadémie vied. 322 p.

Giannatos, G., 2004. Conservation action plan for the golden jackal Canis aureus L. in Greece. Athens: WWF Greece. $47 \mathrm{p}$.

Giannatos, G., Marinos, Y., Maragou, P., Catsadorakis,
G., 2005. The status of the golden jackal (Canis aureus L.) in Greece. Belgian Journal of Zoology, 135 (2): 145-149.

Guimarães, N., BučKo, J., Urban, P., 2018. The evolution of the presence of the golden jackal in Slovakia. In GianNAtos, G., Banea, O.C., Hatlauf, J., Sillero-Zubiri, C., Georgiadis C., Legakis, A. (eds). Proceedings of the 2nd international jackal symposium, Marathon Bay, Attiki, Greece 2018. Hellenic Zoological Archives, 9: 144-145.

Guimarães, N., BuČKO, J., Urban. P., 2019. The rise of a carnivore, the evolution of the presence of the golden jackal in Slovakia. Folia Zoologica, 68 (2): 66-71. https://doi. org/10.25225/fozo.046.2019

Hatlauf, J., Hackländer, K., 2016. Current status of a spreading meso-carnivore in Austria, the golden jackal (Canis aureus). Mammalian Biology - Zeitschrift für Säugetierkunde, 81: 3-18.

Hayward, M.W., Porter, L., Lanszki, J., Kamler, J.F., Beck, J.M., Kerleyc, G.I.H., Macdonald, D.W., Montgomery, R.A., Parker, D.M., Scottu, D.M., O'BrienK, J., YARNEL, R.W., 2017. Factors affecting the prey preferences of jackals (Canidae). Mammalian Biology - Zeitschrift für Säugetierkunde, 85: 70-82. https:// doi.org/10.1016/j.mambio.2017.02.005

Hell, P., Bleho, Š., 1995. Novodobý výskyt šakala obyčajného (Canis aureus) na Slovensku [Contemporary occurrence of jackal (Canis aureus) in Slovakia]. Folia Venatoria, 25: 183-187.

Hell, P., RAJSKÝ, D., 2000. Immigrationen des Goldschakals in die Slowakei im Jahrhundert [Immigration of the golden jackal to Slovakia in the 20th century]. Beiträge zur Jagd- und Wildforschung, 25: 143-147.

Heltai, M., Szemethy, L., Lanszky, J., CsánYi, S., 2000. Returning and new mammal predators in Hungary: the status and distribution of golden jackal (Canis aureus), raccoon dog (Nyctereutes procyonoides) and raccoon (Procyon lotor) in 1997-2000. Beiträge zur Jagd-und Wildforschung, 26: 95-102.

Heltai, M., Pallos Z., Szabó L., Mihály, M., Lanszky, J., 2018. Golden jackal population dynamics in certain study areas of Hungary - examples for hectic population change and invasion. In Giannatos, G., Banea, O.C., Hatlauf, J., Sillero-Zubiri, C., Georgiadis C., Legakis, A. (eds). Proceedings of the 2nd international jackal symposium, Marathon Bay, Attiki, Greece 2018. Hellenic Zoological Archives, 9: 144-145

Hoffmann, M., Arnold, J., Duckworth, J.W., Jhala, Y., KAMLER, J.F., KROFEL, M., 2018. Canis aureus (errata version published in 2020). The IUCN Red List of Threatened Species 2018: e.T118264161A46194820. [cit. 0507-2020]. https://dx.doi.org/10.2305/IUCN.UK.2018-2. RLTS.T118264161A163507876.en.

Ivanov, G., Karamanlidis, A., Stojanov, A., Melovski, D., Avukatov, V., 2016. The re-establishment of the golden jackal (Canis aureus) in FYR Macedonia: implications for conservation. Mammalian Biology - Zeitschrift für Säugetierkunde, 81: 326-330.

JANOviČová, D., 2016. Prínos Ernesta Bethlenfalvyho k výskumu vysokohorskej biológie $\mathrm{v}$ Tatrách [The contribution of Ernest Bethlenfalvy to the research of alpine biology in the Tatras]. Oecologia Montana, 25: 1-35. 
Jhala, Y. V., Moehlman, P.D., 2008. Canis aureus. IUCN 2010. IUCN Red List of Threatened Species. Version 2011.1. 010.2. [cit. 2017-09-05]. http://www.iucnredlist. org

JiRkŮ, M., DostáL, D., RobovskÝ, J., Š́́LeK, M., 2018. Reproduction of the golden jackal (Canis aureus) outside current resident breeding populations in Europe: evidence from the Czech Republic. Mammalia, 82: 592-595.

Kidawa, D., KowalczyK, R., 2011. The effects of sex, age, season and habitat on diet of the red fox Vulpes vulpes in northeastern Poland. Acta Theriologica, 56: 209-218. doi:10.1007/s13364-011-0031-3

Koepfli, K.-P., Pollinger, J., Godinho, R., Robinson, J., Lea, A., Hendricks, S., Schweizer, R.M., Thalmann, O., Silva, P., Fan, Z., Yurchenko, A.A., Dobrynin, P., Makunin, A., Cahill, J.A., Shapiro, B., Álvares, F., Brito, J.C., Geffen, E., Leonard, J.A., Helgen, K.M., Johnson, W.E., O'Brien, S.J., VAN ValKenburGH, B., WAYNE, R.K., 2015. Genome-wide evidence reveals that African and Eurasian golden jackals are distinct species. Current Biology, 25: 2158-2165.

KoubeK, P., ČervenÝ, J., 2007. The golden jackal (Canis aureus) - a new mammal species in the Czech Republic. Lynx, n. s. (Praha), 38: 103-106.

KowalczyK, R., KolodZIEJ-SobocińsKa, M., RuczyŃsKa, I., WóJCIK, J.M., 2015. Range expansion of the golden jackal (Canis aureus) into Poland: first records. Mammal Research, 60: 411-414.

KowalczyK, R., WudarczyK., WóJcik, J.M., OKarma, H., 2020. Northernmost record of reproduction of the expanding golden jackal population. Mammalian Biology - Zeitschrift fur Saugetierkunde, 100 (1): 3. doi: 10.1007/ s42991-020-00009-x

Krofel, M. 2009. Confirmed presence of territorial groups of golden jackals (Canis aureus) in Slovenia. Natura Sloveniae, 11: 65-68. https://doi.org/10.1007/s13364-0150238-9

Krofel, M., РотоČNiK, H., 2008. First record of a golden jackal (Canis aureus) in the Savinja Valley (Northern Slovenia). Natura Sloveniae, 10 (1): 57-62.

Krofel, M., Giannatos, G., Ćirovič, D., Stoyanov, S., Newsome, T.M., 2017. Golden jackal expansion in Europe: a case of mesopredator release triggered by continent-wide wolf persecution? Hystrix, the Italian Journal of Mammalogy, 28 (1) 9-15. doi: 10.4404/hystrix-28.1-11819

Kryštufek, B., Tvrtkovic, N., 1990. Range expansion by Dalmatian jackal population in the 20th century (Canis aureus Linnaeus, 1758). Folia Zoologica, 39: 291-296.

Kryštufek, B., Murariu, D., Kurtonur, C., 1997. Present distribution of the golden jackal Canis aureus in the Balkans and adjacent regions. Mammal Review, 27 (2): 109-114.

LansZKi, J., Heltai, M., 2002. Feeding habits of golden jackal and red fox in south-western Hungary during winter and spring. Mammalian Biology, 67: 129-136.

LanszKi, J., Heltai, M., Szabó, L., 2006. Feeding habits and trophic niche overlap between sympatric golden jackal (Canis aureus) and red fox (Vulpes vulpes) in the Pannonian ecoregion (Hungary). Canadian Journal of Zoology, 84: $1647-1656$.
Lanszki, J., Kurys, A., Heltai, M., CsÁnYi, S., Ács, K., 2015. Diet composition of the golden jackal in an area of intensive big game management. Annales Zoologici Fennici, 52 (4): 243-255. https://doi.org/10.5735/086.052.0403

Lanszki, J., Kurys, A., Szabó, L., Nagyapáti, N., Porter, L.B., Heltai, M., 2016. Diet composition of the golden jackal and the sympatric red fox in an agricultural area (Hungary). Folia Zoologica, 65 (4): 310-322.

Lanszki, J., Schally, G., Heltai, M., Ranc, N., 2018. Golden jackal expansion in Europe: First telemetry evidence of a natal dispersal. Mammalian Biology, 88: 81-84. https://doi.org/10.1016/j.mambio.2017.11.011

Linnell, J.D.C., KaCzensky, P., Wotschikowsky, U., Lescureux, N., Boitani, L., 2015. Framing the relationship between people and nature in the context of European conservation. Conservation Biology, 29 (4). doi: 10.1111/cobi.12534

LODGE, D.M., 1993. Biological invasions: lessons for ecology. Trends in Ecology \& Evolution, 8: 133-137. doi: 10.1016/0169-5347(93)90025-K

Macdonald, D.W., 1979. The flexible social system of the golden jackal, Canis aureus. Behavioral Ecology and Sociobiology, 5 (1): 17-38.

Malez, V., 1984. The zooarcheological data as the basis of colonizing the Markova cave on the island Hvar. In 9th Yugoslavian speleological congress. Congress proceedings, p. 617-621.

Maran, T., 2015. Emergence of the "howling foxes": a semiotic analysis of initial interpretations of the golden jackal (Canis aureus) in Estonia. Biosemiotics, 8 (3): 463-482.

Markov, G., 2012. Golden jackal (Canis aureus L.) in Bulgaria: what is going on? Acta Zoologica Bulgarica, 64, Suppl. 4: 67-71.

Markov, G., LanszKi, J., 2012. Diet composition of the golden jackal, Canis aureus in an agricultural environment. Folia Zoologica, 61 (1): 44-48.

MošAnský, A., 1983. Teriofauna východného Slovenska a katalóg mamaliologických zbierok Východoslovenského múzea. III. Čast' (Carnivora 2) [Mammal fauna of Eastern Slovakia and catalogue of the East Slovakian Museum. III. Part (Carnivora 2)]. Zbornik Východoslovenského Múzea v Košiciach - Prírodné Vedy, 24: 105-125.

MošAnskÝ, A., 1995. Vlk šakal (Canis aureus) na Slovensku [Golden jackal (Canis aureus) in Slovakia]. In URBAN, P., BALÁž, D. (eds). Výskum a ochrana cicavcov na Slovensku 2. Zbornik referátov z konferencie. Zvolen, 13. - 14.10.1995. Banská Bystrica: Slovenská agentúra životného prostredia, p. 107-108.

Möckel, R., 2000. Ein Goldschakal (Canis aureus) in Südbrandenburg: Erstnachweis für Deutschland [A golden jackal (Canis aureus) in southern Brandenburg: first evidence for Germany]. Säugetierkundliche Informationen, 4: 477-481.

NAGY, J., 1959. Berichtigung zur Szunyoghys „Systematischer Revision des ungarländischen Schakals, gleichzeitig eine Bemerkung über das Rohrwolf-Problem“ [Correction to Szunyoghy's "Systematic revision of the Hungarian jackal, at the same time a comment on the reed wolf problem"]. Säugetierkundliche Mitteilungen, 7 (2): $62-64$. 
NeGI, T., 2014. Review on current worldwide status, distribution, ecology and dietary habits of golden jackal, Canis aureus. Octa Journal Environmental Research, 2 (4): 338-359.

Newsome, T.M., Greenville, A.C., Ćirović, D., Dickman, C.R., Johnson, C.N., Krofel, M., Letnic, M., Ripple, W.J., Ritchie, E.G., Stoyanov, S., Wirsing, A.J., 2017. Top predators constrain mesopredator distributions. $\mathrm{Na}$ ture Communications, 8: 154-169.

Paulauskas, A., Ražanské, I., RadziJevskaja, J., Nugaraité, N., Gedminas, V., 2018. The golden jackal Canis aureus - a new species in the Baltic countries. $B i$ ologija, 64 (3): 203-207.

Penezić, A., ĆIrović, D., 2015. Seasonal variation in diet of the golden jackal (Canis aureus) in Serbia. Mammal Research, 60 (4): 309-317.

PyšKová, K., Storch, D., HoráČeK, I., KauzÁl, O., Pyšek, P., 2016. Golden jackal (Canis aureus) in the Czech Republic: the first record of a live animal and its long-term persistence in the colonized habitat. ZooKeys, 641: 151163. https://doi.org/10.3897/zookeys.641.10946

Radović, A., Kovačić, D., 2010. Diet composition of the golden jackal (Canis aureus L.) on the Pelješac Peninsula, Dalmatia, Croatia. Periodicum Biologorum, 112 (2): 219-224.

RAJSKÝ, D., NAGY, Z., 1998. Výskyt šakala zlatého (Canis aureus) na Slovensku [Some aspects of the occurrence of golden jackal (Canis aureus) in Slovakia]. Slovenský Veterinársky Časopis, 23 (1): 34-35.

Rajský, D., Hell, P., Sokol, J., 2005. Šakal zlatý na Slovensku [Golden jackal in Slovakia]. Naše Pol'ovníctvo, 8: $16-17$.

Ranc, N., Krofel, M., Ćirović, D., 2018. Canis aureus (errata version published in 2019). The IUCN Red List of Threatened Species 2018: e.T118264161A144166860. [cit. 2020-10-02].

Rutkowski, R., Krofel, M., Giannatos G., Ćirović, D., Mannil, P., Volokh, A.M., Bogdanowicz, W., 2015. A European concern? Genetic structure and expansion of golden jackals (Canis aureus) in Europe and the Caucasus. PLoS One, 10 (11): e0141236. https://doi.org/10.1371/ journal.pone.0141236

Saisamorn, A., Duengkae, P., Pattanavibool, A., DuangChantrasiri, S., Simcharoen, A., Smith, J.L.D., 2019. Spatial and temporal analysis of leopards (Panthera pardus), their prey and tigers (Panthera tigris) in Huai Kha Khaeng Wildlife Sanctuary, Thailand. Folia Oecologica, 46: 73-82.

Sillero-Zubiri, C., Hoffmann, M., Macdonald, D.W., 2004. Canids: foxes, wolves, jackals and dogs: status survey and conservation action plan. [online]. 2nd ed. IUCN/SSC Action Plans for the Conservation of Biological Diversity. Gland, Switzerland: IUCN - The World Conservation Union. 430 p. [cit. 05-07-2020]. http:// www1.nina.no/lcie_new/pdf/634989770626215825_Sillero-Zubiri\%20IUCN\%20Canid\%20action\%20plan.pdf

Slamka, M., Kaštier, P., Schwarz, M., 2017. The golden jackal in Slovakia. Canid Biology and Conservation, 20 (9): 38-41.
Sommer, R., Benecke, N., 2005. Late-Pleistocene and early Holocene history of the canid fauna of Europe (Canidae). Mammalian Biology, 70: 227-241.

Spassov, N., 1989. The position of jackals in the Canis genus and life history of the golden jackal (Canis aureus L.) in Bulgaria and on the Balkans. Historia Naturalis Bulgarica, 1: 44-56.

Spassov, N., Acosta-Pankov, I., 2019. Dispersal history of the golden jackal (Canis aureus moreoticus Geoffroy, 1835) in Europe and possible causes of its recent population explosion. Biodiversity Data Journal, 7: e34825. https://doi.org/10.3897/BDJ.7.e34825

Stoyanov, S., 2012. Golden jackal (Canis aureus) in Bulgaria: current status, distribution, demography and diet. In Đorđević, N. (ed.). International symposium on hunting "Modern aspects of sustainable management of game populations". Zemun-Belgrade, Serbia, 22-24 June 2012. Zemun: University of Belgrade, Faculty of Agriculture, p. 48-56.

STRATFORD, J.,2015. Goldenjackal inLithuania, a consideration of its arrival, impact and status. Zoology and Ecology, 25 (4): 277-287. doi: 10.1080/21658005.2015.1073894

Szabó, L., Heltai, M., Lanszki, J., 2006. River Tiscia as a green corridor in the spread of golden jackal in Hungary. Vadbiológia 12: 47-54.

Szabó, L., Heltai, M., LanszKi, J., Szöcs, E., 2007. An indigenous predator, the golden jackal (Canis aureus L. 1758) spreading like an invasive species in Hungary. Bulletin of the University of Agricultural Sciences and Veterinary Medicine, Cluj-Napoca, 63-64: 230-235.

Szabó, L., Heltai, M., Szöcs, E., LANSZKi, J., LehoczKi, R., 2009. Expansion range of golden jackal in Hungary between 1997 and 2006. Mammalia, 73: 307-311.

SzunYoGHy, J., 1957. Systematische Revision des ungarländischen Schakals, gleichzeitig eine Bemerkung über das Rohrwolf-Problem [Systematic revision of the Hungarian jackal, at the same time a remark about the problem of the Austrian Rohrwolf]. Annales Musei Historico-naturalis Hungarici, 8: 425-433.

SzUNYOGHY, J., 1959. A nádifarkas [Golden jackal]. Vertebrata Hungarica, 1 (1): 74-88.

Šálek, M., Červinka, J., Banea, O., Krofel, M., Ćirović, D., Selanec, I., Penezić, A., Grill, S., Riegert, J., 2014. Population densities and habitat use of the golden jackal (Canis aureus) in farmlands across the Balkan Peninsula. European Journal of Wildlife Research, 60: 193-200. doi:10.1007/ s10344-013-0765-0

Tóth, T., Krecsák, L., Szücs, E., Heltai, M., Huszár, G., 2009. Record of the golden jackal (Canis aureus L., 1758) in Hungary from 1800 until 2007, based on literature survey. North-Western Journal of Zoology, 5: 386-405.

Trouwborst, A, Krofel, M., Linnell, J.D.C., 2015. Legal implications of range expansions in a terrestrial carnivore: the case of the golden jackal (Canis aureus) in Europe. Biodiversity and Conservation, 24: 2593-5610. doi:10.1007/s10531- 015-0948-y

Urban, P., Ambros, M., ČerneckÝ, J., Uhrin, M., 2019. Červený zoznam cicavcov Slovenska [The Red List of Mammals of Slovakia]. In Urban, P., Lukáčová, A. 
(eds). Výskum a ochrana cicavcov na Slovensku. Zbornik abstraktov zo 14. celoštátnej vedeckej konferencie s medzinárodnou účastou. Banská Bystrica, 14. - 15. 11. 2019. Banská Bystrica: Univerzita Mateja Bela, Fakulta prírodných vied, p. 42.

Urban, P., Ambros, M., ČerneckÝ, J., Uhrin, M., 2020. The Red List of mammals of Slovakia. Biologia, Bratislava. In press.

Urban, P., BučKo, J., Kušík, P., 2017. Šakal zlatý na Slovensku - ako ho vníma verejnost'? [Golden jackal in Slovakia - how is perceived by the public?]. Quaestiones Rerum Naturalium, 4 (1): 1-31.

Urban, P., RaJskÝ, D., 2018. Bibliography on Canis aureus in Slovakia (Carnivora: Canidae). Lynx, n. s. (Praha), 49: 295-307.

Uzelac, A., Klun, I., Ćirović, D., Penezić, A., Ćirković, V., Duurković-Duaković, O., 2019. Detection and ge- notyping of Toxoplasma gondii in wild canids in Serbia. Parasitology International, 73: 101973.

Weingarth, K., Gahbauer, M., Heurich, M., Müller, J., LeIBL, F., 2012. Second record of a golden jackal (Canis aureus) in Germany. Säugetierkundliche Informationen, 8: 443-446.

ŽIAK, D., URBAN, P., 2001. Červený (ekosozologický) zoznam cicavcov (Mammalia) Slovenska [(Red (ecosozological) list of mammals (Mammalia) of Slovakia)]. In BALÁž, D., Marhold. K., Urban, P. (eds). Červený zoznam rastlín a živočichov Slovenska. Ochrana prírody 20 Suplement. Banská Bystrica: Štátna ochrana prírody Slovenskej republiky, p. 154-156.

Received July 20, 2020 Accepted October 5, 2020 